\title{
Depression Tendencies, Social Skills, and Loneliness among College Students in Yogyakarta
}

\author{
Alya Fauziyyah ${ }^{1}$ E Sutarimah Ampuni ${ }^{2}$ \\ 1,2Faculty of Psychology Universitas Gadjah Mada
}

\begin{abstract}
This research is aimed to examine the role of social skills in depression among college students through the mediation of loneliness. As many as 645 college students in Yogyakarta $($ Male $=180$, Female $=465)$ participated in this study. Social skills were measured using a Social Skills Scale, depression was measured using Beck Depression Inventory-II (BDI-II), and loneliness was measured using UCLA Loneliness Scale version 3, which were adapted into Bahasa Indonesia. Regression analysis with a simple mediation model showed that, as expected, social skills negatively contributed to depression with the mediation of loneliness. This means that lower social skills were associated with higher loneliness and in turn contributed to increased tendencies towards depression among college students. Additional analysis found that levels of social skills, loneliness, and depression differed among college students in different years, with students in the fifth years and beyond showed lower social skills and higher scales of loneliness and depression. Furthermore, analysis revealed that depression symptoms were indicated for $51 \%$ of the respondents in which levels varied from mild to severe.
\end{abstract}

Keywords: college students; depression; loneliness; mental health; social skills; Yogyakarta

Depression is a psychiatric disorder with a very high rate of prevalence. At least about 350 million people worldwide suffer from depression in their lives, of which only $17 \%$ seek psychiatric help (World Health Organization, 2012). In Indonesia, there are still many people suffering with depression who have not received help due to lack of awareness (Hawari, 2011). Indonesian Basic Health Research results showed that in $2013,11.6 \%$ of the adult population in Indonesia experienced emotional mental disorders such as anxiety and depression (Badan Penelitian dan Pengembangan Kesehatan Kementerian Kesehatan RI, 2013).

Depression can occur in various age ranges, from children to elderly. According to Neiger (1988), teenagers are among the most vulnerable groups to develop depression. Unfortunately, the signs of depression in teenagers are often regarded as something normal in their stage of development (Aditomo \& Retnowati, 2004). In fact, various studies have shown that depression is prevalent among college students (Furr, McConnel, Westefeld, \& Jenkins, 2001; Harber \& Runyon, 1984). In line with that, according to the American College Health Association (2015), depression is a psychological disorder that has the second highest prevalence in college students after anxiety disorder. In Indonesia, Natalia (2006) discovered that from 110 samples of college students, $61.8 \%$ of them showed depression symptoms 
with varying degrees of severity. Therefore, depression in college students is a crucial issue in mental health and early diagnosis and treatment is essential (Aditomo \& Retnowati, 2004).

According to the Diagnostic and Statistical Manual of Mental DisordersFifth Edition (DSM-V), depression denotes negative changes in mood or feelings from a person's normal condition (baseline) characterized by grief, emptiness, and significant changes in a person's cognition and affection and these changes affect these functions in various aspects of life (American Psychiatric Association, 2013). According to DSM-V, in general people who are depressed show symptoms of sadness and/or loss of interest in daily activities (APA, 2013). Specifically, symptoms of depression may include significant changes in weight or appetite, sleep deprivation, slowing physical movements, fatigue and loss of energy, feelings of worthlessness or excessive guilt, decreased ability to concentrate, and suicidal ideation (APA, 2013). Based on the DSM diagnostic criteria, Beck, Steer, and Brown (1996) developed a depression inventory known as Beck Depression Inventory-Second Edition (BDI-II) which is the latest version of Beck Depression Inventory (BDI) by Beck (1967). The symptoms of depression in BDI-II are grouped into two aspects, namely the cognitive-affective and somatic aspects (Beck, et al., 1996).

Depression is caused by various internal and external factors. Internal factors include genetics, biology, personality, cognitive factors, as well as interpersonal factors (Hankin \& Abela, 2005). External factors include stressful negative life events and social factors (Hankin \& Abela, 2005). College students face many changes in their social environment and this makes them more prone to depression. One factor influencing the susceptibility of depression is social skills (Cacioppo \& Patrick, 2008; Seepersad, 2014). Social skills in the APA Dictionary of Psychology is defined as a set of learned skills that allows individuals to interact according to the social context (VandenBos, 2007). Michelson, Sugai, Wood, and Kazdin (1983) mentioned that social skills involve three aspects, i.e. verbal and nonverbal responses, as well as cognitive processes.

Social skills for students are necessary to adapt in social environments, to build new social relationships, and to develop and maintain social relationships (Chapdelaine \& Alexitch, 2004). According to Chapdelaine and Alexitch (2004), adequate social skills can reduce the level of culture shock to students due to their socio-cultural transition. People with low social skills tend to develop low selfesteem, feelings of shame, unhappiness, dissatisfaction, and loneliness (Ozben, 2013).

Previous research indicated that low social skills are associated with loneliness (Boivin, Hymel, \& Bukowski, 1995; Dill \& Anderson, 1999). Peplau and Perlman (1979) defines loneliness as individual perceptions of social isolation, or subjective experiences of solitude. According to Cacioppo, Hawkley, and Thisted (2010), the prediction of depression and the individual perceptions of loneliness and social isolation might linearly correlate.

Boivin, et al. (1995) identified that loneliness played a mediating effect in the relationship between someone's social condition and their depressive symptoms. Similarly, Dill and Anderson (1999) mentioned that the negative relationship between social skills and depression may be mediated by feelings of loneliness. According to Dill and Anderson (1999), 
shyness as a manifestation of low social skills possessed by individuals tends to inhibit their social relationships with others, increasing feelings of loneliness. These feelings of loneliness subsequently may lead to depression (Dill \& Anderson, 1999).

This research is focused on college students in Yogyakarta, because Yogyakarta is recognized as a city of education in Indonesia. On the other hand, Yogyakarta recorded high statistics in poor mental health cases in conjunction with the highest number of severe mental disorders in Indonesia (Badan Penelitian dan Pengembangan Kesehatan Kementerian Kesehatan RI, 2013). Furthermore, the prevalence of emotional mental disorders such as depression and anxiety are also very high, i.e. $8.1 \%$ of the population of Yogyakarta (Badan Penelitian dan Pengembangan Kesehatan Kementerian Kesehatan RI, 2013). Due to this high rate of mental disorders in Yogyakarta, research in this area is very crucial in the attempt to find the solutions.

From the above explanation, it can be concluded that college students are vulnerable to depression. Social skills can be a factor affecting the tendency of depression in students and the effect is mediated by loneliness. This study is aimed to examine whether this model is supported if applied to college students in Yogyakarta. The hypothesis proposed in this study was "social skills contribute negatively to the tendency of depression with the mediation of loneliness".

\section{Methods}

Participants. Participants were 645 college students aged 18-24 years old from Yogyakarta universities and surrounds (male $=180$, female $=465$ ). Data was collected utilizing questionnaires distributed online by snowball method. The average age of participants was 21 years old (30\%). Based on the college year, the first year students consisted of 120 respondents (19\%), second year students consisted of 105 respondents (16\%), third year students consisted of 142 respondents $(22 \%)$, fourth year students consisted of 259 respondents $(40 \%)$, the fifth year and beyond consisted of 19 respondents (3\%).

This study involved three variables, i.e. the tendency of depression, social skills, and loneliness. Instruments measuring these three variables are described below.

Depression tendency. To measure depression, we used Beck Depression Inventory-II (Beck, et al., 1996) adapted into Bahasa Indonesia by Ginting, Naring, Veld, Srisayekti, and Becker (2013). This scale consists of 21 items with 4 choices of answers based on the criteria of DSM. The Indonesian version of BDI-II Scale shows a reliability coefficient $\alpha$ of 0.90 and has proven to be able to distinguish between depressive and non-depressive groups (Ginting, et al., 2013). In conducting regression analysis, we did not use clinical depression categorization, but used the raw score of BDI-II.

Social skills. To measure students' social skills, we used the Social Skills Scale which was developed by Ramdhani (1996) and has been modified by Nugraini (2015). This scale consists of 24 items based on the social skill aspects mentioned by Michelson et al. (1983) namely verbal, nonverbal, and cognitive processes. The scale quality was quite effective with the reliability coefficient of $\alpha=0.876$ and item total correlation ranged from $r=0.287$ to $r=0.664$ (Nugraini, 2015).

Loneliness. To measure loneliness, we used UCLA Loneliness Scale version 3 (Russell, 1996) translated and undertaken 
for the purpose of this study. The scale consists of 18 items with a reliability coefficient of $\alpha=0.875$ and the item total correlation ranged between 0.315 and 0.746 .

Data collection was conducted by the distribution of online questionnaires which contained the above three scales to college students in Yogyakarta. Data analysis was performed using the 22.0 version of SPSS (Statistical Package for Social Sciences) program with additional macro from Hayes (2013) called PROCESS to test the mediation. As additional analysis, ANOVA was also conducted to examine differences in the three variables based on some demographic characteristics of the participants.

\section{Results}

Descriptives. The data descriptions are shown in Table 1. Analysis of variance comparing the three variables by gender and the college year identified that: (1) depression tendencies, social skills, and loneliness did not differ between male and female, (2) based on the college year, there were differences in levels of depression tendencies $(F=2.462, p<0.05)$, social skills $(F=3.229, p<0.05)$, as well as loneliness $(F$ $=2.840, p<0.05)$, where depression tendencies and loneliness were highest in the fifth year. The lowest level of social skills was revealed by participants in the second and fifth year. From Figure 1 it can be seen that the students in the fifth year onwards showed the highest tendencies of depression and loneliness, as well as low level social skills.

The effect of social skills and loneliness on depression tendencies. The results of the regression analysis revealed that social skills and loneliness significantly contributed toward depression tendencyies $\left(R^{2}=0.21 ; p<0.01\right)$. Loneliness mediated the effects of social skills to depression ( $a b=$ 0.29; $p<0.01$ ); controlling loneliness makes the role of social skills, which was initially significant $(c=-0.34 ; p<0.01)$ become insignificant $\left(c^{\prime}=-0.05 ; p=0.12\right)$. The relation between social skills, loneliness, and depression tendencies are presented in Figure 2.

Table 1

Data description

\begin{tabular}{lccccccc}
\hline & \multicolumn{3}{c}{ Depression Tendency } & \multicolumn{2}{c}{ Social Skills } & \multicolumn{2}{c}{ Loneliness } \\
\hline Total & $N$ & $M$ & $S D$ & $M$ & $S D$ & $M$ & $S D$ \\
\hline Gender & 645 & 15.43 & 10.3 & 78.50 & 14.1 & 40.24 & 10.6 \\
$\quad$ Men & & & & & & & \\
Women & 180 & 14.19 & 10.1 & 79.24 & 14.4 & 40.77 & 10.4 \\
\hline College Year & 465 & 15.91 & 10.3 & 78.22 & 14.0 & 40.03 & 10.6 \\
$\quad$ First year & & & & & & & \\
Second year & 120 & 15.88 & 10.2 & 76.60 & 14.5 & 41.10 & 11.2 \\
$\quad$ Third year & 105 & 16.98 & 10.6 & 75.63 & 14.0 & 41.53 & 10.6 \\
$\quad$ Fourth year & 142 & 14.51 & 9.6 & 79.12 & 14.2 & 40.22 & 9.9 \\
$\quad$ Fifth year and so forth & 259 & 14.71 & 10.1 & 80.45 & 13.5 & 38.92 & 10.3 \\
\hline & 19 & 20.58 & 14.0 & 76.28 & 16.2 & 45.68 & 11.4 \\
\hline
\end{tabular}






Figure 1. Social Skills, Depression Tendencies, and Loneliness Based on the College Year

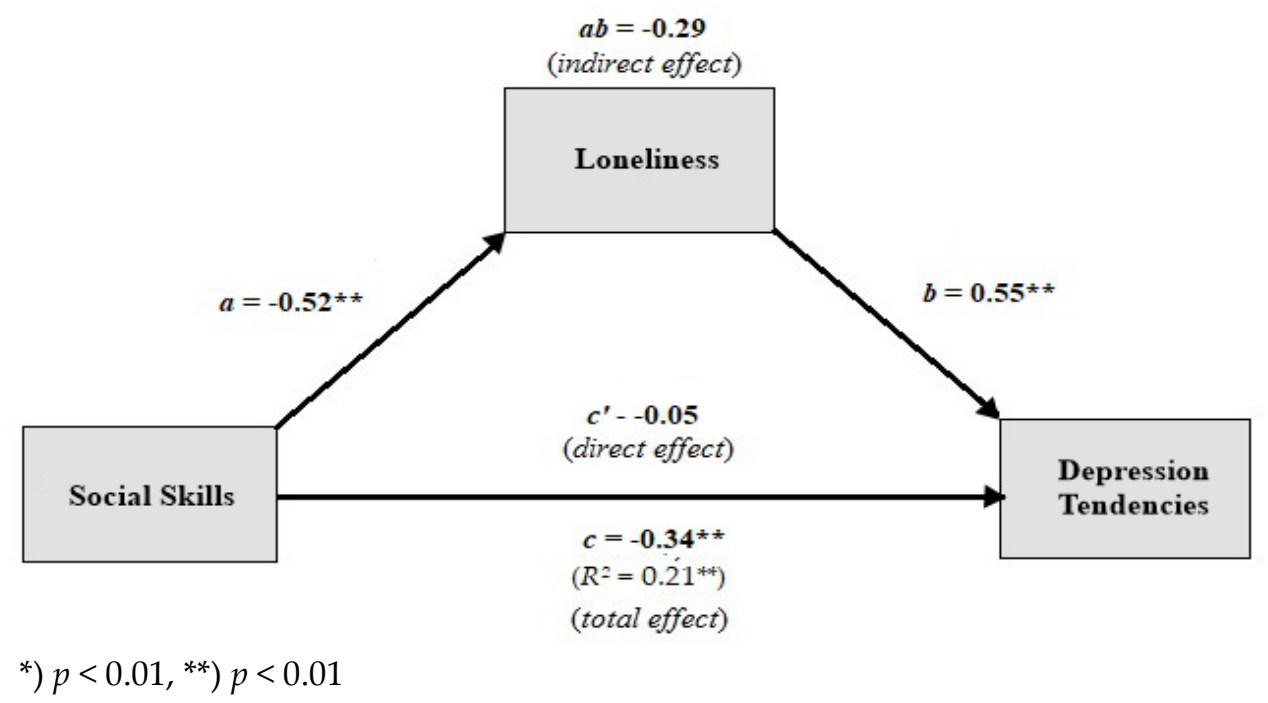

Figure 2. The role of Social Skills on Depression Tendencies with Loneliness as Mediator

From these results, it can be concluded that low social skills lead to increased loneliness and in turn, increased depression tendencies among college students. Conversely, high social skills may lead to a decrease in loneliness, thus depression tendencies are decreased among college students. The ratio between indirect effect and total effect $\left(P_{M}=0.85\right)$ and the ratio between indirect effect and direct effect $\left(R_{M}=5.85\right)$ demonstrated that the role of social skills toward depression is strongly influenced by loneliness, therefore loneliness fully mediated the role of social skills toward depression tendencies.
As additional analysis, we examined the depression rates of participants based on clinical categorization. For this purpose, BDI-II scores of the subjects were categorized into a clinical depression categorization introduced by Beck et al. (1996), i.e. the total score of 0-13 goes into the normal classification or no symptoms of depression, the score $14-19$ as mild depression, the score of $20-28$ as moderate depression, and score $29-63$ as severe depression. The surprising finding was that the $51 \%$ of participants indicated depression clinically, with $18 \%$ being classified as mild depression, $21 \%$ of subjects classified as moderate depression, and $12 \%$ as severe depression. 


\section{Discussion}

This study supports our prediction that social skills play a role in depression tendencies for college students. It was demonstrated that the decrease in social skills contributes $21 \%$ to the increase of depression tendencies. The influence of social skills on depression tendencies was mediated by loneliness. These findings are in line with several studies which indicated that high social skills can hinder individuals from depression tendencies (Dill \& Anderson, 1999; Garland \& Fitzgerald, 1998; Reed, 1994; Segrin \& Rynes, 2009).

The findings of this study also support previous research by Fiori and Consedine (2013) that loneliness as a subjective evaluation of the lack of individual social relations provides a $46-53 \%$ mediation effect on the relation of social interaction with one's mental health. This may occur because individuals with low social skills tend to have difficulty in building positive and deep social relationships (Wittenberg \& Reis, 1986).

Dill and Anderson (1999) also explain that poor social skills can increase the maladaptive arousal in social situations. Poor social skills lead individuals to negative feelings toward his/her interpersonal relationships, both in quantity (e.g. feeling lack of friends) and quality (feeling lack of close relationships), thus making them feel lonely. These lack of social relationships in turn will make students vulnerable to feelings of loneliness which can lead to depression (Kraus, et al., 2009; Segrin \& Rynes, 2009; Shiovitz-Ezra \& Leitsch, 2010). On the contrary, the research of Jose and Lim (2014) informs that if social connectedness is well established it can be a protective factor that may prevent depression (Jose \& Lim, 2014).
Students in the different college years showed different tendencies of depression, social skills, and loneliness. Data from this study indicated that college students in the fifth year of college and beyond showed a higher level of depression and loneliness and lower level of social skills compared with other groups. This finding is in accordance with that of Smith and Renk (2007) which showed that the academic demands of the final task is a significant stressor in the final year of college.

In order to understand the results of this study in the context of students in Yogyakarta, we conducted a short interview with two students in the fifth year, they stated that they felt high amounts of pressure from their social environment because they had not successfully completed their final project. One of the interviewees mentioned that in the fifth year there were feelings of distress as well as guilt because he had not yet succeeded in completing the final task (i.e. undergraduate thesis). Another interviewee mentioned that during final assessment deadline time, the inferior feelings he endured heightened and his confidence to complete the final task diminished due to his peers having graduated before him. On the other hand, many of their friends have graduated so that access to the friendship is not as solid as before. These could be potential factors which trigger loneliness and depression among college students in the fifth year and beyond.

This high tendency of depression in the fifth year students onwards indicates the necessity for focus and special attention towards this group of students. According to Smith and Renk (2007), support provided by people around students can reduce perceived pressures that the finalyear encounter. Support groups for final 
year students may become an effective measure to reduce the tendency of depression (Smith \& Renk, 2007). A support group can facilitate final-grade students to stay intact with an appropriate social network, thus reduce loneliness and avoid depression.

The surprising finding from this research is the fact that there were high indications of depression among college students in Yogyakarta. Data showed that as many as $51 \%$ of the 645 college students showed symptoms of depression with various severity levels, i.e. $18 \%$ in the category of mild depression, $21 \%$ in the category of moderate depression, and $12 \%$ in the category of severe depression. This infers that depression is a very common psychological problems among college students in Yogyakarta, just like in other parts of the world (Harber \& Runyon, 1984; Furr, et al., 2001).

Given the high level of depression and other psychological problems among students, mental health services of students such as campus counseling become a very important service, as stated by Kitzrow (2003). Counseling services play a vital role in higher education institutions, because through this service college students can seek help to solve their problems as well as to assist students in facing challenges and achieving their goals (Kitzrow, 2003). This research endorses that colleges in Yogyakarta are in deep need to provide psychological services for students.

This study showed that social skills and loneliness contributed $21 \%$ to college student's depression tendencies, thus there is $79 \%$ variance of tendencies not explained in this study. According to Hankin and Abela (2005), both external and internal factors such as stressful negative life events, biological factors, as well as genetic, personality, cognitive, and interpersonal or social factors are interacting to generate depression. Further research is suggested to explore the factors that affect depression among college students.

\section{Conclusion}

According to the results of this research, it can be concluded that social skills, with the mediation of loneliness, negatively contributed as much as $21 \%$ to the depression tendencies among college students. It is also founded that loneliness fully mediated the connection between social skills and depression tendencies.

\section{Suggestion}

Early recognition of the impacts of low social skills and loneliness might be helpful to reduce depression tendencies for college students. It is recommended to take social skills and loneliness into account in developing the intervention to overcome this issue.

\section{Reference}

Aditomo, A. \& Retnowati, S. (2004). Perfeksionisme, harga diri, dan kecenderungan depresi pada remaja akhir. Jurnal Psikologi, 30(2), 1-14.

American College Health Association. (2015). American college health association-National college health assessment II: Reference group executive summary spring 2015. Hanover: American College Health Association.

American Psychiatric Association. (2013). Diagnostic and statistical manual of mental disorders, $5^{\text {th }}$ edition. Washington DC: American Psychiatric Association.

Badan Penelitian dan Pengembangan Kesehatan Kementerian Kesehatan RI. 
(2013). Riset kesehatan dasar 2013. Jakarta: Kementerian Kesehatan RI.

Beck, A. T. (1967). Depression: Causes and treatment. Philadelphia: University of Pennsylvania Press.

Beck, A. T., Steer, R. A., \& Brown, G. (1996). Beck Depression Inventory-II manual. San Antonio: The Psychological Corporation.

Boivin, M., Hymel, S., Bukowski, W. M. (1995). The roles of social withdrawal, peer rejection, and victimization by peers in predicting loneliness and depressed mood in childhood. Development and Psychopathology, 7, 765-785. doi: 10.1017/ S0954579400006830

Cacioppo, J. T., Hawkley, L. C., \& Thisted, R. A. (2010). Perceived social isolation makes me sad: 5-year cross-lagged analyses of loneliness and depressive symptomatology in the Chicago Health, Aging, and Social Relations Study. Psychology and Aging, 25(2), 453463. doi: $10.1037 / \mathrm{a} 0017216$

Cacioppo, J. T., \& Patrick, W. (2008). Loneliness: Human nature and the need for social connection. New York: W. W. Norton \& Company, Inc.

Chapdelaine, R. F., \& Alexitch, L. R. (2004). Social skills difficulty: Model of culture shock for international graduate students. Journal of College Student Development, 45(2), 167-184.

Dill, J. C., \& Anderson, C. A. (1999). Loneliness, shyness, and depression: The etiology and interrelationships of everyday problems in living. In $\mathrm{T}$. Joiner \& J. C. Coyne (Eds.), The interactional nature of depression: Advances in interpersonal approaches (pp. 93-125). Washington, D.C.: American Psychological Association.

Fiori, K. L., \& Consedine, N. S. (2013). Positive and negative social exchanges and mental health across the transition to college: Loneliness as a mediator. Journal of Social and Personal Relationships, 30(7), 920-941. doi: 10.1177/0265407512473863

Furr, S. R., McConnel, G. N., Westefeld, J. S., \& Jenkins, J. M. (2001). Suicide and depression among college students: A decade later. Professional Psychology: Research and Practice, 32, 97-100.

Garland, M., \& Fitzgerald, M. (1998). Social skills correlates of depressed mood in normal young adolescents. Irish Journal of Psychological Medicine, 15(1), 19-21.

Ginting, H., Naring, G., Veld, W. M. V. D., Srisayekti, W., \& Becker, E. S. (2013). Validating the Beck Deperssion Inventory-II in Indonesia's general population and coronary heart disease patients. International Journal of Clinical and Health Psychology, 13, 235-242. doi: 10.1016/S1697-2600(13)70028-0

Hankin, B. L., \& Abela, J. R. Z. (2005). Development of psychopathology: A vulnerability-stress perspective. California: Sage Publications.

Harber, A. \& Runyon, R. P. (1984). Psychology of adjustment. Illinois: The Dorsey Press.

Hawari, D. (2011). Manajemen stress, cemas, dan depresi. Jakarta: Balai Penerbit FKUI.

Hayes, A. F. (2013). Introduction to mediation, moderation, and conditional process analysis: $A$ regression-based approach. New York: The Guilford Press.

Jose, P. E., \& Lim, B. T. (2014). Social connectedness predicts lower loneliness and depressive symptoms over time in adolescents. Journal of Depression, 3, 154-163. doi: 10.4236/ ojd.2014.34019 
Kitzrow, M. A. (2003). The mental health needs of today's college students: Challenges and recommendations. NASPA Journal, 41(1), 167-181.

Kraus, L. A., Davis, M. H., Bazzini, D. G., Church, M., \& Kirchman, C. M. (2009). Personal and social influences on loneliness: The mediating effect of social provisions. Social Psychology Quarterly, 56(1), 37-53.

Michelson, L., Sugai, D. P., Wood, R. P., \& Kazdin, A. E. (1983). Social skills assessment and training with children. New York: Springer Science + Business Media, LLC.

Natalia, C. B. (2006). Hubungan antara penerimaan diri dengan tingkat depresi pada mahasiswa. Tesis (Tidak dipublikasikan). Fakultas Psikologi Universitas Gadjah Mada, Yogyakarta.

Neiger, B. L. (1988). Adolescent suicide: Character traits of high-risk teenagers. Adolescent, 23, 469-472.

Nugraini, I. (2015). Keterampilan sosial sebagai mediator antara hubungan kecanduan internet dan kesejahteraan psikologis pada remaja. Tesis (Tidak dipublikasikan). Fakultas Psikologi Universitas Gadjah Mada, Yogyakarta.

Ozben, S. (2013). Social skills, life satisfaction, and loneliness in Turkish University students. Social Behavior and Personality, 41(2), 203-214. doi: 10.2224/sbp.2013.41.2.203

Peplau, L. A., \& Perlman, D. (1979). Blueprint of social psychological theory of loneliness. In M. Cook, \& G. Wilson (Eds.), International conference on love and attraction (pp. 101-110). Oxford: Pergamon Press Ltd.

Ramdhani, N. (1996). Perubahan perilaku dan konsep diri remaja yang sulit bergaul setelah menjalani pelatihan keterampilan sosial, Jurnal Psikologi, 23(1), 13-20.

Reed, M. K. (1994). Social skills training to reduce depression in adolescents. Adolescence, 29(114), 293-302.

Russell, D. (1996). UCLA Loneliness Scale (Version 3): Reliability, validity, and factor structure. Journal of Personality Assessment, 66, 20-40.

Seepersad, S. (2014). Is loneliness just another form of depression? Cited from https://www.psychologytoday.com/ in $9^{\text {th }}$ March 2017.

Segrin, C., \& Rynes, K. N. (2009). The mediating role of positive relations with others in associations between depressive symptoms, social skills, and perceived stress. Journal of Research in Personality, 43, 962-971. doi: 10.1016/ j.jrp.2009.05.012

Shiovitz-Ezra, S., \& Leitsch, S. A. (2010). The role of social relationships in predicting loneliness: The national social life, health, and aging project. Social Work Research, 34(3), 157-167. doi: 10.1093/swr/34.3.157

Smith, T., \& Renk, K. (2007). Predictors of academic-related stress in college students: An examination of coping, social support, parenting, and anxiety. NASPA Journal, 44(3), 405-431.

VandenBos, G. R. (2007). APA dictionary of psychology. Washington, DC: American Psychological Association.

Wittenberg, M. T., \& Reis, H. T. (1986). Loneliness, social skills, and social perception. Personality and Social Psychology Bulletin, 12(1), 121-130.

World Health Organization. (2012). World health statistics 2012. Geneva: WHO Press. 